JOSETA: Journal of Socio Economic on Tropical Agriculture

Volume 1 Nomor 1: 104-115 April (2019)

JOSETA: Journal of Socio Economic on Tropical Agriculture http://joseta.faperta.unand.ac.id

ISSN : $2686-0953$ (online)

\title{
ANALISIS KELAYAKAN FINANSIAL USAHA PERKEBUNAN JERUK NIPIS (Citrus Aurantifolia Swingle) di NAGARI PADANG GANTIANG KECAMATAN PADANG GANTING KABUPATEN TANAH DATAR
}

\author{
Gunawan Ade Putra ${ }^{1}$, Syahyana Raesi ${ }^{1}$, Mahdi ${ }^{1}$ \\ ${ }^{1}$ Jurusan Sosial Ekonomi Fakultas Pertanian Unand, Padang, indonesia \\ *raesi_s@yahoo.com \\ Received: $20^{\text {th }}$ Februari, 2019; $1^{\text {st }}$ Revision: $10^{\text {th }}$ Maret, 2019; Accepted: $19^{\text {th }}$ April, 2019
}

\begin{abstract}
Abstrak
Kabupaten Tanah Datar adalah salah satu daerah penghasil batu kapur di Sumatera Barat dengan petani yang dahulunya menanam jeruk nipis sebagai usaha kebun rumah tangga yang berguna untuk memenuhi kebutuhan sehari-hari kini bergeser dalam bisnis perkebunan untuk memenuhi kebutuhan pasar regional dan provinsi. Namun, tidak ada perhatian dari pemerintah dalam mendukung keberlanjutan pertanian jeruk nipis. Tujuan dari penelitian ini adalah untuk mendeskripsikan teknik budidaya kapur dan menganalisis kelayakan perkebunan kapur masyarakat. Penelitian ini menggunakan metode survei dan metode pengambilan sampel menggunakan purposive sampling. analisis data yang digunakan adalah deskriptif kualitatif dan kuantitatif. Hasil penelitian ini menunjukkan bahwa budidaya jeruk nipis di daerah penelitian belum sesuai dengan rekomendasi literatur, tetapi pertanian jeruk nipis di daerah penelitian layak untuk dilanjutkan dengan nilai $\mathrm{B} / \mathrm{C}$ Ratio $=1,80, \mathrm{NPV}=73.522 .488$, IRR $=35 \%$. Petani harus lebih memperhatikan teknik budidaya dan perhatian pemerintah pada pembentukan kelompok tani dan konseling.
\end{abstract}

Kata Kunci : Jeruk Nipis, B/C rasio, NPV, IRR

\begin{abstract}
Tanah Datar regency is one of the limestone producing areas in West Sumatra with farmers who formerly planted lime as a home garden business that is useful to meet daily needs now shifting in the plantation business to meet the needs of regional and provincial markets. However, there is no attention from the government in supporting the sustainability of lime farming. The purpose of this study is to describe the techniques of lime cultivation and analyze the feasibility of the community lime plantation. This research used survey method and sampling method using purposive sampling. data analysis used is descriptive qualitative and quantitative. The results of this study indicate that the cultivation of lemon in the area of research has not been in accordance with the recommendation of the literature, but the lime farming in the study area is feasible to proceed with the value of $B / C$ Ratio $=1.80, N P V=$ $73.522 .488, I R R=35 \%$. Farmers should pay more attention to cultivation techniques and the government's attention on the formation of farmer groups and counseling.
\end{abstract}

Keywords :Lime, Financial, B/C Ratio, NPV, IRR 


\section{PENDAHULUAN}

Sektor pertanian mempunyai peranan penting pada negara berkembang seperti di Indonesia.Sektor pertanian meliputi subsektor tanaman pangan dan hortikultura, tanaman perkebunan, peternakan, kehutanan dan perikanan.Sasaran sektor pembangunan pertanian diarahkan kepada peningkatan produksi sebagai salah satu dasar untuk meningkatkan pendapatan petani (Wayan dan Didiek, 2004 : 13).

Menurut Ashari (1995:11) salah satu sub sektor pertanian adalah hortikultura. Sub sektor hortikultura dibeberapa negara berkembang mengalami beberapa kendala, diantaranya yaitu rendahnya nilai pendapatan petani, keterbatasan pengetahuan petani, keterbatasan lahan yang dimiliki petani dan posisi penawaran pada pihak petani yang kurang kuat. Pola produksi dan distribusi produk hortikultura pada umumnya masih tergantung pada musim. Subsektor hortikultura khususnya buah-buahan saat ini mendapatkan perhatian banyak orang karena tersedianya peluang pasar buah-buahan baik dalam negeri maupun luar negeri yang didukung oleh kondisi lahan di Indonesia yang sangat potensial untuk produksi buah-buahan, salah satunya jeruk nipis.

Kabupaten Tanah Datar merupakan salah satu daerah penghasil jeruk nipis di Sumatra Barat dengan petani yang dahulunya menanam jeruk nipis sebagai usaha tanaman pekarangan yang berguna untuk memenuhi kebutuhan sehari-hari sekarang beralih dalam usaha perkebunan untuk memenuhi kebutuhan pasar daerah maupun provinsi.Perubahan dalam pengelolaan usahatani masyarakat dalam tanaman jeruk nipis maka berubah pula penggunaan biaya-biaya seperti biaya yang diperlukan untuk memproduksi.Untuk itu perlu dilakukan analisis kelayakan terhadap usaha perkebunan jeruk nipis ini untuk mengetahui apakah usaha perkebunan jeruk yang dilakukan petani saat sekarang layak atau tidak untuk dilakukan dilihat dari berbagai aspek analisis kelayakan usaha.

Analisis finansial sangat penting dilakukan dalam usaha perkebunan jeruk nipis ini karena analisis kelayakan finansial ini bertujuan untuk mengetahui layak atau tidak layaknya suatu usaha dilakukan dengan membandingkan biaya yang dikeluarkan dan manfaat yang diperoleh serta jangka waktu dalam pengembalian suatu investasi yang digunakan dalam usaha perkebunan jeruk nipis.

Salah satu daerah sentra Jeruk nipis diSumatera Barat adalah diKabupaten Tanah Datar tepatnya di Nagari Padang Gantiang dimana jeruk nipis dimanfaatkan sebagai bahan baku utama dalam pembuatan produk sabun cuci piring, sirup dan obat-obatan. Dalam hal ini terlihat tanaman jeruk nipis mempunyai nilai ekonomis.Jeruk nipis pada umumnya diNagari Padang Gantiang diusahakan di pekarangan rumah tetapi sekarang sudah diusahakan dalam bentuk perkebunan saat ini belum ada penelitian atau kajian mengenai analisis kelayakan finansial jeruk nipis di Nagari Padang Gantiang.Perubahan pengelolaan usahatani masyarakat dalam tanaman jeruk nipis menimbulkan perubahan pula dalam biaya-biaya yang diperlukan untuk mengusahakannya seperti biaya pemeliharaan .Untuk itu perlu dilakukan analisis kelayakan terhadap usaha perkebunan jeruk nipis ini untuk mengetahui apakah usaha perkebunan jeruk yang dilakukan petani saat sekarang layak atau tidak untuk dilakukan dilihat dari berbagai aspek analisis kelayakan usaha.

Berdasarkan latar belakang dan perumusan masalah yang dirumuskan di atas, maka yang menjadi tujuan penelitian adalah :

1. Mendeskripsikan kultur teknis perkebunan jeruk nipis rakyat di Nagari Padang Gantiang Kecamatan Padang Gantiang Kabupaten Tanah Datar.

2. Menganalisis kelayakan usaha perkebunan jeruk nipis rakyat di Nagari Padang Gantiang Kecamatan Padang Gantiang Kabupaten Tanah Datar dari aspek finansial.

\section{METODE PENELITIAN}

Penelitian ini telah dilaksanakan di Nagari Padang Gantiang Kecamatan Padang Gantiang.Lokasi ini dipilih secara sengaja (purposive).Pemilihan lokasi ini karena Nagari Padang Gantiang merupakan nagari dengan lahan terluas penghasil jeruk nipis di Kabupaten Tanah Datar. Penelitian ini dilaksanakan selama 1 bulan, terhitung sejak 11 November- 11 Desember 2016 sesuai dengan surat rekomendasi penelitian oleh Fakultas Pertanian Universitas Andalas. 
Metode Penelitian ini menggunakan metode survei menurut (Nazir, 2003 : 56) metode survei yaitu penyelidikan yang diadakan untuk memperoleh fakta-fakta dari gejala-gejala yang ada dan mencari keterangan-keterangan secara faktual, baik instuisi sosial, ekonomi atau politik dari suatu kelompok ataupun daerah. Metode survei membedah dan menguliti serta mengenal masalah-masalah serta mendapatkan pembenaran terhadap keadaan dan praktik-praktik yang sedang berlangsung.Metode survei pada penelitian ini dilakukan untuk menyelidiki secara faktual tentang kelayakan finansial dari usaha perkebunan jeruk nipis di Nagari Padang Gantiang Kecamatan Padang Gantiang.

Dalam penelitian ini metode yang digunakan dalam pengambilan sampel adalah purposive sampling. Purposive Sampling adalah teknik penentuan sampel dengan pertimbangan tertentu dan menentukan kriteria sebelum melakukan penelitian (Sugiyono, 2012 : 85). Berdasarkan data yang diperoleh dari Badan Penyuluhan Pertanian Kecamatan Padang Gantiang jumlah petani yang mengusahakan jeruk nipis adalah 60 orang petani dengan memiliki lahan $0,5 \mathrm{Ha}-2 \mathrm{Ha}$ dan berstatus milik sendiri. Jumlah petani sampel pada penelitian ini yang memenuhi kriteria adalah 30 orang

Data yang dikumpulkan dalam penelitian ini adalah data primer dan data sekunder. Data primer diperoleh dengan cara wawancara langsung pada petani pengusaha jeruk nipis dengan panduan kuisioner yang telah dipersiapkan terlebih dahulu. Data yang dikumpulkan berhubungan dengan aspek personal petani, status kepemilikan lahan, tingkat suku bunga kredit investasi yang berlaku, umur tanaman jeruk nipis, teknik budidaya yang dilakukan, penggunaan input, harga input, upah tenaga kerja, produktivitas, dan harga produksi dalam $(\mathrm{Rp} / \mathrm{Kg})$.

Data sekunder diperoleh dari instansi yang berkaitan kelayakan usaha perkebunan jeruk nipis, yaitu Badan Pusat Statistik (BPS), Dinas Pertanian Perkebunan dan Kehutanan Kabupaten Tanah Datar, dan instansi lainnya yang membantu dalam ketersediaan data yang dibutuhkan dalam penelitian ini

Agar tercapai tujuan yang diinginkan dalam penelitian ini digunakan dua metode analisis data, yaitu analisis deskriptif melalui pengamatan langusung di lapangan. Alat analisis untuk tujuan kedua yaitu kuantitatif :

\section{Analisis Finansial}

Analisis finansial tanaman jeruk nipis ini menggunakan analisa criteria investasi. Kriteria investasi yang digunakan antara lain :

a. Benefit Cost Ratio (B/C Ratio)

b. Net Present Value (NPV)

c. Internal Rate Return (IRR), kemudian dilanjutkan dengan Analisis Sensitivitas

\section{Benefit Cost Ratio}

Menurut Pasaribu (2010 : 55), B/C Ratio merupakan perbandingan antara jumlah Net Present Value positif dengan jumlah Net Present Value negative, hal ini menunjukkan bahwa besarnya biaya dan investasi untuk memperoleh suatu manfaat. Rumus B/C ratio adalah sebagai berikut :

$$
\frac{\mathrm{B}}{\mathrm{C}} \text { Ratio }=\sum_{t=1}^{n} \frac{\frac{B t}{(1+i)^{t}}}{\frac{C t}{(1+i)^{t}}}
$$

dimana :

$\mathrm{Bt}=$ benefit yang diperoleh tiap tahun dari direct benefit dari tanaman jeruk nipis (produksi jeruk nipis)

$\mathrm{Ct}=$ cost yang dikeluarkan tiap tahun dari penanaman jeruk nipis

$\mathrm{n}=$ jumlah tahun dari produktif tanaman jeruk nipis di lapangan yaitu 15 tahun

$\mathrm{i}=$ tingkat suku bunga kredit investasi dan suku bunga pinjaman Bank Nagari yang berlaku di lokasi penelitian yaitu $13 \%$

https://doi.org/10.25077/joseta.v1i1.14 
$\mathrm{t}=$ umur proyek selama umur produktif tanaman jeruk nipis yang ditemui di lapangan yaitu

$1,2,3, \ldots, \mathrm{n}$

Langkah menghitung $\mathrm{B} / \mathrm{C}$ ratio adalah :

a. Cari nilai sekarang dari benefit tiap tahun, dengan cara mengalikan benefit tiap tahun dengan

discount faktor ( $d f)$ pada tingkat suku bunga yang berlaku, lalu dijumlahkan.

b. Cari nilai sekarang cost tiap tahun dengan cara mengalikan cost tiap tahun dengan discount faktor (df) pada tingkat suku bunga yang berlaku lalu jumlahkan.

c. Hasil Presesnt Value Total Benefit (PVTB) dibagi dengan Present Value Total Cost (PVTC) sehingga didapatkan $\mathrm{B} / \mathrm{C}$ ratio.

Jika didapatkan hasil yang diperoleh berupa :

$\mathrm{B} / \mathrm{C}>1$ artinya usaha perkebunan jeruk nipis ini layak dilaksanakan

$\mathrm{B} / \mathrm{C}=1$ artinya usaha perkebunan jeruk nipis ini masih layak untuk dijalankan

$\mathrm{B} / \mathrm{C}<1$ artinya usaha perkebunan jeruk nipis ini tidak layak dilaksanakan

\section{Net Present Value}

Menurut Gittinger (1986), Net Present Value (NPV) merupakan selisih antara nilai sekarang arus manfaat (benefit) dengan nilai sekarang arus biaya (cost) selama umur proyek. Net Present Value (NPV) atau nilai kini netto adalah kriteria investasi yang banyak digunakan dalam mengukur apakah suatu usaha layak (fesible) atau tidak. NPV dapat diartikan sebagai nilai sekarang dari arus kas yang ditimbulkan oleh investasi.Dalam menghitung NPV perlu ditentukan tingkat suku bunga yang relevan.

NPV dinyatakan dengan rumus :

$\mathbf{N P V}=\sum_{t=1}^{n} \frac{B t-C t}{(1+i)^{t}}$

$\frac{1}{(1+i)^{t}}=$ discount factor pada tahun $t$

dimana :

$\mathrm{Bt}=$ benefit yang diperoleh tiap tahun dari direct benefit dari tanaman jeruk nipis (produksi jeruk nipis)

$\mathrm{Ct}=$ cost yang dikeluarkan tiap tahun dari penanaman jeruk nipis

$\mathrm{n}=$ jumlah tahun dari produktif tanaman jeruk nipis di lapangan yaitu 15 tahun

$\mathrm{i}=$ tingkat suku bunga kredit investasi dan suku bunga pinjaman Bank Nagari yang berlaku

di lokasi penelitian $13 \%$.

$\mathrm{t}=$ umur proyek selama umur produktif tanaman jeruk nipis yang ditemui dilapangan yaitu

$1,2,3 \ldots, \mathrm{n}$

Langkah menghitung NPV adalah :

a. Cari nilai sekarang dari benefit tiap tahun, dengan cara mengalikan benefit tiap tahun dari usaha perkebunan jeruk nipis, dengan discount factor $(d f)$ pada tingkat suku bunga yang berlaku lalu jumlahkan.

b. Cari nilai sekarang dari cost tiap tahun dengan cara mengalikan cost tiap tahun dari usaha perkebunan jeruk nipis dengan discount faktor $(d f)$ pada tingkat suku bunga yang berlaku lalu jumlahkan.

c. Hasil Present Value Total Benefit (PVTB) dikurang dengan Present Value Total Cost (PVTC) sehingga didapatkan nilai NPV. 
Jika hasil NPV yang diperoleh :

NPV $>0$, artinya suatu usaha layak dan bermanfaat untuk dilaksanakan

$\mathrm{NVP}=0$, maka proyek tersebut mengembalikan persis sebesar pengeluaran (arus biaya)

NPV <0,artinya usaha tersebut tidak layak untuk dilaksanakan karena tidak dapat menghasilkan manfaat senilai pengorbanan atau biaya yang dikeluarkan

\section{Internal Rate of Return}

Menurut Gittinger (1986 : 81), Internal Rate of Return (IRR) merupakan tingkat bunga maksimum yang dapat dibayarkan oleh proyek atas nama penggunaan sumberdaya karena proyek masih membutuhkan dana untuk biaya-biaya produksi dan investasi.

Langkah menghitung IRR adalah :

a. Hitung nilai cash flow yang merupakan selisih antara benefit dan cost dari usaha perkebunan jeruk nipis tiap tahun selama umur proyek.

b. Hitung nilai discount factor dari tingkat suku bunga yang ada dilapangan yaitu $13 \%$.

c. Hitung nilai Present Worth of Cash Flow (PW of CF). Apabila nilai PW of CF positif maka tingkat suku bunga harus dinaikkan lagi sampai mendapatkan nilai NPV mendekati nol ataupun negatif. Sebaliknya jika PW of CF negatif maka tingkat suku bunga diturunkan lagi sampai mendapatkan nilai NPV mendekati nol ataupun positif. Selisih tingkat suku bunga yang harus dinaikkan ataupun diturunkan biasanya 5\% dari tingkat suku bunga awal. Setelah didapatkan NPV positif dan negatif masukkan kerumus berikut :

$\operatorname{IRR}=i^{\prime}+\left(i^{\prime \prime}-i^{\prime}\right) \frac{N P V^{\prime}}{N P V^{\prime}-N P V V^{\prime \prime}}$

dimana :

$i^{\prime} \quad=$ tingkat suku bunga yang lebih rendah

$i^{\prime \prime} \quad=$ tingkat suku bunga yang lebih tinggi

$\mathrm{NPV}^{\prime} \quad=$ nilai NPV pada tingkat bunga $i^{\prime}$

$\mathrm{NPV}^{\prime \prime} \quad=$ nilai NPV pada tingkat bunga $i^{\prime \prime}$

Bila IRR >OCC yaitu tingkat suku bunga kredit investasi yang berlaku di lokasi penelitian berarti proyek layak untuk dilaksanakan.

Bila IRR <OCC berarti proyek tidak layak untuk dilaksanakan

\section{Analisis Sensitivitas}

a. Dalam penelitian ini perhitungan analisis sensitivitas untuk analisa kelayakan tanaman jeruk nipis di analisis dalam beberapa keadaan dengan menggunakan asumsi:

b. Terjadinya peningkatan biaya

c. Terjadinya penurunan jumlah produksi $25 \%$ akibat kekeringan

d. dan banjir yang dialami. Hal ini berdasarkan keterangan dari petani jeruk nipis di Nagari Padang Gantiang Kecamatan Padang Ganting.

e. Penurunan harga jual karena harga jeruk nipis di Nagari Padang Gantiang ini sangat fluktuatif.

\section{HASIL DAN PEMBAHASAN}

\section{Kondisi Usaha Perkebunan}

Kondisi usaha perkebunan jeruk nipis di Nagari Padang Gantiang akan dijelaskan sesuai dengan tahapan budidaya tanaman perkebunan yaitu: Persiapan lahan, Penananaman , Pemeliharaan, Panen. Untuk lebih rinci dijelaskan sebagai berikut:

1. Persiapan Lahan

Pemilihan areal yang dilakukan oleh petani hanya untuk melihat kemiringan dan kekosongan lahan, kemudian dilakukan penyiangan lahan tersebut dari gulma.Setelah itu dilakukan pembuatan lubang 
tanam.Dari 15 petani sampel sebanyak 13 orang (87\%) dari petani sampel langsung melakukan penanaman bibit pada saat pembuatan lubang tanam. Sedangkan 2 orang (13\%) dari petani sampel membiarkan lubang tanam sekitar 2-3 minggu sebelum dilakukan penanaman bibit .

\section{Penanaman}

Secara umum jarak tanam yang dipakai petani sampel dalam penanaman jeruk nipis adalah $6 \times 6$ meter dengan jumlah tanaman jeruk nipis rata-rata 1 hektar lahan adalah 250 - 350 batang yang pola tanamnya disesuaikan dengan kondisi alam lahan. Dari 15 petani sampel sebanyak 13 orang (87\%) melakukan penanaman bibit ke lahan pada umur 1-2 bulan, sedangkan 2 orang (13\%) memindahkan bibit hasil cangkok pada umur kurang dari 1 bulan. Jarak tanam yang digunakan petani sampel memakai jarak yang ideal 6x6 meter.Mengenai pemupukan pada saat penanaman semua petani sampel hanya menambahkan pupuk kandang pada saat penanaman dilakukan.

3. Pemeliharaan

Pemeliharaan tanaman merupakan kegiatan yang penting dalam usahatani jeruk nipis, karena akan mempengaruhi produktifitas tanaman jeruk nipis. Kegiatan yang pemeliharaan yang dilakukan oleh petani sampel berhubungan dengan pemeliharaan tanaman jeruk nipis yaitu penyulaman, pengairan, penyiangan, pemangkasan, pemupukan, dan pengendalian HPT. Semua kegiatan yang dilakukan petani sudah sesuai dengan literatur.

\section{Panen}

Pemanenan jeruk nipis pertama kali pada umur 3 tahun.Tanaman jeruk nipis berbuah lebat pada umur 5 tahun. Intensitas pemanenan buah jeruk nipis dilakuakan petani sampel maksimal 2 kali dalam 1 bulan, petani sampel melakukan kegiatan panen sendiri dan kadang-kadang dibantu oleh Tenaga kerja Dalam Keluarga (TKDK). Perawatan yang digunakan petani sampel untuk melakukan pemanenan yaitu galah.Galah digunakan untuk mengambil buah yang tidak dapat dijangkau oleh tangan. Warna buah jeruk nipis adalah hijau dengan tekstur mulus, wadah pengumpulan buah yang dipanen biasanya petani sampel langsung memasukan jeruk nipis kedalam karung.Petani sampel telah melakukan sortasi hasil panen jeruk nipis dengan kriteria buah bewarna hijau dengan tekstur mulus dan tidak busuk.Setelah panen hasilnya langsung dijual kepada pedagang pengumpul yang ada di Nagari Padang gantiang, bahkan kadang-kadang langsung padagang pengumpul tersebut menjemput kelahan petani.Hal ini dikarenakan para petani sampel tidak memiliki gudang khusus untuk penyimpana jeruk nipis setelah panen.

Biaya yang dimaksud dalam penelitian ini adalah segala biaya yang dikeluarkan oleh petani selama umur proyek yang sedang berlangsung yaitu 15 tahun.Adapun jenis-jenis biaya yang termasuk kedalam kegiatan usaha perkebunan jeruk nipis adalah biaya investasi, biaya operasional dan pemeliharan serta biaya lain-lain (other cost).

\section{Biaya Investasi}

a. Sewa Tanah

Nilai tanah ini dihitung sesuai dengan nilai sewa tanah di daerah penelitian.Untuk satu hektar lahan jeruk nipis di Nagari Padang Gantiang sewa tanahnya rata-rata Rp 2.000.000 pertahunnya.

b. Biaya Pembuatan Pondok

Bangunan ini bersifat semi-permanen dengan dinding kayu ukuran pondok rata-rata adalah $4 \mathrm{~m} x$ $2 \mathrm{~m}$.Pondok yang dimaksud adalah tempat petani menyimpan alat-alat pertaniannya dan tempat beristirahat ketika bekerja dilahan tersebut.Biaya yang dikeluarkan untuk pembuatan pondok yaitu sebesar Rp 4.000.000.rincian biaya pembuatan pondok dapat dilihat Tabel 1.

Tabel 1. Biaya Pembuatan Pondok Pada Perkebunan Jeruk Nipis di Nagari Padang Gantiang

\begin{tabular}{|lll|}
\hline No & Jenis Biaya & Total Biaya $(\mathbf{R p})$ \\
\hline 1 & Seng & 750.000 \\
2 & Kayu & 1.500 .000 \\
3 & Tonggak & 280.000 \\
\hline
\end{tabular}




\begin{tabular}{|lll|}
\hline 4 & Paku & 50.000 \\
5 & Kayu atap & 120.000 \\
6 & Lantai & 300.000 \\
7 & Upah borong & 800.000 \\
8 & Biaya tak terduga & 200.000 \\
\hline Total Biaya Pembuatan Pondok & 4.000 .000 \\
\hline
\end{tabular}

c. Biaya Pengadaan Alat

Dalam usaha perkebunan jeruk nipis alat-alat yang digunakan oleh petani di Nagari Padang Gantiang adalah cangkul, parang, sabit, tong penyemprot, ember, kapak, gergaji, galah, dan karung. Peralatan ini digunakan untuk mengolah lahan, penyiangan, pemupukan, dan panen.Pengeluaran biaya untuk pembelian peralatan dihitung berdasarkan jenis alat yang digunakan dalam satu tahun.Harga peralatan yang digunakan yang berlaku pada saat penelitian dilakukan dapat dilihat pada tabel 2.

Tabel 2. Harga Peralatan Pada Perkebunan Jeruk Nipis Di Nagari Padang Gantiang

\begin{tabular}{|lll|}
\hline No & Nama Alat & Harga $(\mathbf{R p})$ \\
\hline 1 & Cangkul & 70.000 \\
2 & Parang & 40.000 \\
3 & Sabit & 30.000 \\
4 & Tong Penyemprot & 450.000 \\
5 & Ember & 10.000 \\
6 & Kapak & 40.000 \\
7 & Gergaji & 60.000 \\
8 & Galah & 10.000 \\
9 & Karung & 12.000 \\
\hline
\end{tabular}

Pada umur tanaman belum menghasilkan, alat-alat yang digunakan adalah cangkul, parang, sabit, tong penyemprot, ember, kapak, dan gergaji. Cangkul, parang, dan sabit digunakan pada saaat pembukaan lahan sedangkan tong penyemrot untuk penyiraman tanaman, ember untuk pengangkutan air, kapak dan gergaji untuk menebang pohon jeruk nipis yang sudah mati. Sedangkan ketika tanaman sudah menghasilkan diperlukan alat tambahan untuk pemanenan buah jeruk nipis yaitu galah yang digunakan untuk mengambil buah jeruk nipis yang jauh dan langsung dimasukkan ke dalam karung dan diikat dengan tali kemudian dibawa keluar kebun.

Biaya peralatan dalam hal ini tergolong kedalam biaya investasi karena biaya peralatan dikeluarkan pada saat awal proyek, dan pergantian peralatan dilakukan berdasarkan umur ekonomis dari masingmasing alat. Biaya pergantian alat disebut sebagai Replacement cost.

\section{Biaya operasional dan pengadaan (operational and maintenance/ O\&M)}

a. Biaya bibit

Bibit jeruk nipis yang dipakai oleh petani di Nagari Padang Gantiang adalah bibit jeruk nipis lokal. Bibit ini diperoleh dengan cara membeli di Pasar Padang Ganting. Harga rata-rata pembelian bibit untuk perbatangnya sebesar Rp. 15.000. Kebutuhan dalam satu hektar lahan adalah sebanyak 277 batang, sehingga biaya bibit harus dikeluarkan sebesar Rp 4.155.000 untuk luas lahan satu hektar.

b. Biaya pupuk

Petani melakukan pemupukan 2 kali dalam setahun.maka pengeluaran biaya untuk pembelian pupuk dihitung berdasarkan kebutuhan pupuk dalam satu tahun.Harga pupuk yang dipakai adalah harga pupuk yang berlaku pada saat penelitian dilakukan.Harga pupuk kandang perkilogramnya adalah Rp 10.000 . Pupuk kandang yang diberikan petani sampel lebih kurangnya sebanyak 119,11 kg / Ha untuk tanaman yang berumur dibawah 3 tahun dengan total biaya per Ha sebesar Rp 1.191.100. 
Untuk tanaman yang sudah berumur 3 tahun keatas, pemakaian pupuk untuk 1 hektar luas lahan lebih kurang sebanyak 346,25 kg dengan total biaya per Ha sebesar Rp 3.462.500.

c. Biaya tenaga kerja

Semua kegiatan dalam usaha perkebunan jeruk nipis ini dilakukan oleh tenaga kerja dalam keluarga maupun luar keluarga.Untuk lahan yang cukup luas, mulai dari kegiatan pembukaan lahan sampai kegiatan panen biasanya membutuhkan tenaga kerja luar keluarga dengan sistem upah. Perhitungan jam kerja dilakukan dengan menggunakan satuan Hari Kerja Pria (HKP), dimana untuk satu HKP waktu yang digunakan adalah 7 jam dengan tingkat upah $\mathrm{Rp} 100.000$ per hari. Biaya rata-rata yang dikeluarkan oleh petani jeruk nipis untuk upah tenaga kerja pada tahun pertamanya yaitu untuk kegiatan pembukaan lahan, pengolahan lahan, penanaman, penyiangan, dan pemupukan awal adalah sebesar Rp 4.600.000 tetapi tidak masuk kedalam biaya tenaga kerja, melainkan dihitung dalam biaya investasi. Selanjutnya pada tahun kedua petani mengeluarkan biaya untuk pemupukan dan penyiangan yaitu $\mathrm{Rp}$ 3.000.000.selanjutnya pada tahun ketiga petani mengeluarkan biaya untuk penyiangan, pemupukan, dan panen yaitu sebesar Rp 3.300.000. Begitu juga untuk tahun ke empat sampai tahun kelima belas.

\section{Biaya lain-lain (Other Cost)}

Biaya lain-lain yang dikeluarkan untuk usaha perkebunan jeruk nipis ini adalah biaya pajak (PBB), dimana biaya pajak yang dikelurakan setiap tahunnya yaitu sebesar Rp 10.000/Ha sesuai dengan pajak (PBB) yang ditetapkan didaerah penelitian per hektarnya.

\section{Biaya Total}

Biaya total diperoleh dengan jalan menjumlahkan seluruh biaya yang dikeluarkan untuk usaha perkebunan jeruk nipis. Biaya total terdiri dari biaya investasi, biaya O\&M dan biaya lain-lain. Adapun biaya lain-lain yang dikeluarkan petani adalah sebesar $\mathrm{Rp} 10.000$,- tiap tahunnya. Untuk dapat mengetahui besarnya biaya total yang dikeluarkan petani per tahun berdasarkan tingkat umur tanaman dapat dilihat pada Tabel 3.

Tabel 3. Biaya Total yang Dikeluarkan dalam Usaha Perkebunan Jeruk Nipis (Rp/Ha/Th)

\begin{tabular}{|llllll|}
\hline Tahun & Biaya Investasi & Sewa Lahan & Biaya O\&M & Biaya Lain-lain & Biaya Total \\
\hline 1 & 8.900 .000 & 30.000 .000 & 6.537 .200 & 10.000 & 45.447 .200 \\
2 & & & 4.982 .200 & 10.000 & 4.992 .200 \\
3 & $20.000^{*}$ & & 9.893 .000 & 10.000 & 9.923 .000 \\
4 & & 9.893 .000 & 10.000 & 9.903 .000 \\
5 & $20.000^{*}$ & 9.893 .000 & 10.000 & 9.923 .000 \\
6 & $140.000^{*}$ & 9.893 .000 & 10.000 & 10.043 .000 \\
7 & $20.000^{*}$ & 9.937 .000 & 10.000 & 9.967 .000 \\
8 & & 9.937 .000 & 10.000 & 9.947 .000 \\
9 & $20.000^{*}$ & 9.937 .000 & 10.000 & 9.967 .000 \\
10 & & 9.937 .000 & 10.000 & 9.947 .000 \\
11 & $710.000^{*}$ & 9.937 .000 & 10.000 & 10.657 .000 \\
12 & & 9.937 .000 & 10.000 & 9.947 .000 \\
13 & $20.000^{*}$ & & 9.937 .000 & 10.000 & 9.967 .000 \\
14 & & & 9.937 .000 & 10.000 & 9.947 .000 \\
15 & $20.000^{*}$ & & 9.937 .000 & 10.000 & 9.967 .000 \\
\hline
\end{tabular}

Jumlah biaya total yang harus dikeluarkan petani adalah sebanyak Rp 180.544.400./Ha / Th

\section{Nilai Sisa}

Biaya penyusutan tidak termasuk sebagai arus biaya karena sudah ditampung dalam pergantian alat dan diakhir tahun dimasukkan kedalam nilai sisa (Salvage Value) yang akan menambah penerimaan dan akan mengurangi biaya. Jadi biaya penyusutan tidak lagi dihitung karena apabila sudah diperhitungkan dalam pergantian alat maka akan terjadi perhitungan ganda. Dalam hal ini nilai sisa dihitung sebagai suatu 
nilai residual (sisa) dari pada kapital aset yang tidak terpakai habis selama umur proyek.Nilai sisa alat ada yang bernilai 0, dikarenakan setelah habis umur ekonomis alat tersebut tidak dapat dijual kembali.Dalam penelitian ini nilai sisa yang diperoleh adalah sebesar Rp 173.000.

\section{B. Produksi dan Manfaat (Benefit)}

Benefit diperoleh dari hasil kali antara jumlah produksi pertahun dengan tingkat harga yang berlaku pada daerah penelitian yaitu sebesar $\mathrm{Rp} 5.000,-/ \mathrm{Kg}$ untuk jeruk nipis. Tanaman jeruk nipis baru berproduksi pada tahun ke 3 dimana jumlah produksi untuk tahun 3-15 diperoleh dari hasil penelitian di lapangan. Untuk mengetahui besarnya benefit petani setiap tahunnya dari usaha perkebunan jeruk nipis dapat dilihat pada Tabel 4.

Tabel 4. Benefit Dalam Usaha Perkebunan Jeruk Nipis (Rp/Ha/Th)

\begin{tabular}{|llll|}
\hline $\begin{array}{l}\text { Umur } \\
\text { Tanaman }\end{array}$ & Produksi $(\mathbf{K g})$ & Harga $(\mathbf{R p} / \mathbf{K g})$ & Benefit $(\mathbf{R p )}$ \\
\hline 1 & - & 3.000 & - \\
2 & - & 3.000 & - \\
3 & $8.384,73$ & 3.000 & 25.154 .182 \\
4 & $9.094,84$ & 3.000 & 27.284 .529 \\
5 & $10.110,08$ & 3.000 & 30.330 .237 \\
6 & $11.056,69$ & 3.000 & 33.170 .077 \\
7 & $12.482,88$ & 3.000 & 37.448 .632 \\
8 & $14.112,29$ & 3.000 & 42.336 .867 \\
9 & $15.714,70$ & 3.000 & 47.144 .100 \\
10 & $17.319,34$ & 3.000 & 51.958 .029 \\
11 & $15.459,72$ & 3.000 & 46.379 .152 \\
12 & $18.151,81$ & 3.000 & 54.455 .430 \\
13 & $10.063,29$ & 3.000 & 30.189 .867 \\
14 & $5.980,92$ & 3.000 & 17.942 .760 \\
15 & $4.262,50$ & 3.000 & 12.787 .500 \\
& & & $173.000^{*}$ \\
\hline Total & $152.193,79$ & & 456.754 .362 \\
\hline
\end{tabular}

Keterangan: *Nilai sisa

\section{Kriteria investasi}

Analisa finansial usaha perkebunan jeruk nipis yang dilakukan di Nagari Padang Gantiang adalah sampai umur 15 tahun. Discount factor yang digunakan adalah 13\% per tahun, disesuaikan dengan tingkat suku bunga pinjaman untuk Kredit Usaha Rakyat (KUR) dari Bank Rakyat Indonesia di Kecamatan Padang Ganting pada tahun 2017.Berdasarkan perhitungan diperoleh kriteria investasi usaha perkebunan jeruk nipis di Nagari Padang Gantiang Kecamatan Padang Gantiang.

Hasil kriteria investasi usaha :

$\begin{array}{ll}\text { B/C Ratio } & =1,80 \\ \text { NPV } & =73.522 .488 \\ \text { IRR } & =35 \%\end{array}$

Berdasarkan hasil kriteria investasi usaha diatas menunjukkan bahwa B/C Ratio $>1$. Hal ini berarti usaha perkebunan Jeruk Nipis feasible untuk dilaksanakan dan dapat diartikan bahwa untuk setiap Rp 1,yang diinventasikan akan memperoleh keuntungan sebesar 0,80 dan manfaat sebesar 1,80 
NPV > 0 artinya keuntungan bersih yang diterima petani selama umur proyek adalah sebesar Rp 73.522 .488 .

Untuk IRR dari hasil analisa yang telah dilakukan diperoleh sebesar 35\%.Bila dibandingkan dengan tingkat bunga komersil yang berlaku pada saat ini yaitu 13\% maka usaha perkebunan jeruk nipis ini feasible untuk dilaksanakan. Hal ini berarti, investasi untuk usaha perkebunan jeruk nipis lebih menguntungkan dari pada menyimpan sejumlah uang yang sama pada bank dengan tingkat bunga 13\%, karena tingkat pengembalian modal diperoleh sebesar 35\% atau lebih besar dari $13 \%$ dari tingkat pengembalian yang diberikan oleh bank.

\section{Analisis Sensitivitas}

Analisis sensitifitas dilakukan untuk melihat apa yang akan terjadi dengan analisa proyek jika ada suatu perubahan dalam dasar-dasar perhitungan biaya atau benefit. Dalam penelitian ini analisis sensitifitas dilakukan berdasarkan terjadinya peningkatan biaya, penurunan produksi, dan perubahan harga.

\section{Analisis Sensitifitas Terhadap Terjadinya Kenaikan Biaya}

Hasil analisis sensitifitas usaha perkebunan jeruk nipis yang dilakukan terhadap kemungkinan terjadinya perubahan biaya yang dikaitkan dengan terjadinya kenaikan inflasi pada Negara Indonesia yaitu sebesar 7\%, maka diperoleh B/C Ratio > 1, NPV > 0, dan IRR > tingkat bunga yang berlaku . Hal ini berarti pada kenaikan biaya sebesar 7\%, usaha perkebunan jeruk nipis ini feasible untuk dilaksanakan.

Hasil kriteria investasi usaha :

$\begin{array}{ll}\text { B/C Ratio } & =1,68 \\ \text { NPV } & =\operatorname{Rp~} 67.081 .504 . \\ \text { IRR } & =32 \%\end{array}$

Berdasarkan hasil kriteria investasi usaha diatas terlihat bahwa B/C Ratio > 1 yang berarti usaha perkebunan jeruk nipis ini masih feasible untuk dilaksanakan. Dimana akan memperoleh keuntungan sebesar 0,68 dan manfaat sebesar 1,68 dengan keuntungan bersih yang diterima selama umur proyek sebesar Rp 67.081.504 dengan tingkat IRR sebesar 32\%.

Dan ketika biaya naik $80 \%$, usaha ini impas karena diperoleh NPV=0.

\section{Analisis Sensitivitas Terhadap Penurunan Produksi}

Berdasarkan hasil survey di lapangan permasalahan yang sedang dihadapi petani jeruk nipis di Nagari Padang Gantiang saat ini adalah kekeringan dan banjir yang menyebabkan turunnya hasil produksi hingga $25 \%$. Akibat terjadinya perubahan hasil produksi tersebut, maka perlu dilakukan analisis sensitifitas yang tujuannya untuk melihat sejauh mana pengaruh penurunan hasil produksi terhadap usaha perkebunan jeruk nipis.

Hasil analisis sensitifitas yang usaha perkebunan jeruk nipis yang dilakukan terhadap perubahan jumlah produksi jeruk nipis yaitu penurunan produksi sebesar $25 \%$ berdasarkan penurunan produksi yang pernah terjadi akibat kekeringan dan banjir yang sampai saat ini masih menjadi permasalahan bagi petani jeruk nipis di Nagari Padang Gantiang. Berdasarkan persentase penurunan produksi tersebut, diperoleh $\mathrm{B} / \mathrm{C}$ Ratio $>1$, NPV $>0$, dan IRR > tingkat bunga yang berlaku .Hal ini berarti pada penurunan produksi sebesar $25 \%$, usaha perkebunan jeruk nipis ini feasible untuk dilaksanakan.

Hasil kriteria investasi usaha :

$\begin{array}{ll}\text { B/C Ratio } & =1,35 \\ \text { NPV } & =\operatorname{Rp~32.145.268~} \\ \text { IRR } & =25 \%\end{array}$


Berdasarkan hasil kriteria investasi diatas terlihat bahwa B/C Ratio > 1 yang berarti usaha perkebunan jeruk nipis ini masih feasible untuk dilaksanakan. Dimana akan memperoleh keuntungan sebesar 0,35 dan manfaat sebesar 1,35 dengan keuntungan yang diterima selama umur proyek sebesar Rp 32.145.268 dengan tingkat IRR sebesar $25 \%$.

Usaha ini mengalami impas ketika terjadi penurunan produksi sebesar 44\% karena diperoleh NPV $=0$

\section{Analisis Sensitifitas Terhadap Penurunan Harga Jual}

Berdasarkan penelitian dilapangan harga jeruk nipis sangat bervariasi.Harga jeruk nipis terendah Rp 800 dan harga tertinggi mencapai Rp 12.000.Akibat terjadinya perubahan harga yangbervariasi tersebut, maka perlu dilakukan analisa sensitifitas yang tujuannya untuk melihat sejauh mana pengaruh perubahan harga terhadap usaha perkebunan jeruh nipis.

Usaha ini mengalami impas ketika terjadi perubahan harga saat harga jeruk nipis sebesar Rp 1.680 $(56 \%)$ karena diperoleh NPV $=0$. Pada saat jeruk nipis dibawah harga impas petani tidak melakukan pemanenan dan membiarkan buah jatuh hingga busuk atau petani memberikan kepada warga sekitar yang tidak memiliki perkebunan jeruk nipis. Petani melakukan kegiatan lain dengan melakukan budidaya komoditi lain seperti padi dan karet pada lahan yang berbeda.

\section{KESIMPULAN}

Berdasarkan hasil penelitian tentang Analisis Finansial Perkebunan Jeuk Nipis (Citrus Aurantifolia Swingle) di Nagari Padang Gantiang, dapat diambil kesimpulan sebagai berikut :

1. Lahan perkebunan jeruk nipis yang diusahakan petani saat ini adalah lahan yang sudah ditanami tanaman hortikultura sebelumnya. Dari segi penanaman dan pemeliharaan masih tergolong seadanya, belum sesuai dengan teknik budidaya jeruk nipis yang baik yang dianjurkan oleh literatur.

2. Usaha perkebunan jeruk nipis di Nagari Padang Gantiang ini layak (feasible) untuk diusahakan bila dilihat dari aspek finansial, yang ditandai dengan diperolehnya B/C Ratio 1,80, NPV Rp 73.522.488 dan IRR 35\%. Sedangkan untuk analisis sensitivitas dilihat berdasarkan : (a) peningkatan biaya sebesar $7 \%$ (b) penurunan produksi sebesar $25 \%$ diperoleh $\mathrm{B} / \mathrm{C}$ Ratio > 1 , $\mathrm{NPV}>0$, dan IRR > OCC artinya usaha perkebunan jeruk nipis ini masih layak untuk diusahakan. (c) penurunan harga jual (26\%) usaha ini mengalami kerugian yaitu dengan B/C ratio $<1$, NPV < 1dan IRR < OCC. Dan usaha ini mengalami impas ketika terjadi kenaikan biaya sebesar 56\%, dan saat harga jeruk nipis sebesar Rp 1.680 karena diperoleh NPV $=0$.

Berdasarkan penelitian yang telah dilakukan mengenai analisis kelayakan finansial perkebunan jeruk nipis sehingga muncul beberapa saran yaitu :

1. Petani sebaiknya lebih memperhatikan cara budidaya jeruk nipis sesuai dengan literatur agar produksi yang hasil lebih maksimal serta sudah mulai mencatat segala transaksi secara sederhana agar para petani mengetahui seberapa besar alur kas masuk dan keluar dari usahatani jeruk nipis ini.

2. Adanya perhatian pemerintah terhadap petani dalam pembentukan kelompok tani, memberikan bantuan permodalan dan membantu penstabilan harga jeruk nipis dipasaran.

3. Diharapkan adanya peran penyuluh serta instansi terkait guna untuk pengembangan usahatani yang lebih maksimal.

\section{DAFTAR PUSTAKA}

AKK. 1990. Budidaya Tanaman Padi.Jakarta : Ashari, S. 1995. Hortikultura Aspek Bubidaya.Jakarta : UI Press. Hal 11

Badan Pusat Statistik. 2015. Sumatera Barat Dalam Angka. Badan Pusat Statistik Sumatera Barat. Padang

Dinas Pertanian Tanaman Pangan Provinsi Sumatera Barat 2014. Pengembangan Buah- Buahan Sumatera Barat. $84 \mathrm{Hal}$.

Gittinger, J.P. 1986. Analisa Ekonomi Proyek Pertanian. Jakarta. UI - Press. 579 Hal. 
Kadariah, Karlina, dan Clive Gray.1978. Pengantar Evaluasi Proyek. Lembaga Penerbit Fakultas Ekonomi Universitas Indonesia. Jakarta. 104 hal.

Kementrian Pertanian. Rencana Strategis Kementrian Pertanian 2015-2019.364 Hal.

Mardikanto. 2007. Pengantar Ilmu Pertanian. Pusat Pengembangan Agrobisnis Dan Perhutanan Sosial. Surakarta. 235 hal.

Nazir, M. 2003. Metode Penelitian. Jakarta. Penerbit Ghalia Indonesia.544 Hal.Pasaribu, A.M. 2012. Perencanaan dan Evaluasi Proyek Agribisnis.Yogyakarta. Lily Publisher. 182 hal.

Rahmadhani, Aulia. 2015. Analisis Finansial Perkebunan Cengkeh (Eugenia aromatica) Rakyat Di Nagari Talang Kecamatan Gunung Talang Kabupaten Solok.[Skripsi]. Fakultas Pertanian. Universitas Andalas. Padang.

Rukmana,. 2003. Jeruk Nipis Prospek Agribisnis, Budidaya, dan Pascapanen. Kanisius.Yogyakarta.55 hal.

Sarwono, B. 1991. Jeruk Nipis Dan Pemanfaatanya. Jakarta : Penebar Swadaya. 88 hal.

Sugiyono. 2012. Metode Penelitian Kuantitatif Kualitatif Dan R\&D. Bandung : Alfabeta. 334 hal.

Wayan, dan Didiek.2004. Peran Subsektor Perkebunan dalam Perekonomian Indonesia. http://www.ipard.com/art_perkebunan/des14-04_wrs-I.asp [15 Desember 2014]. 